6-1-2012

\title{
Entrepreneurship, Muddling Through, And Indian Internet-Enabled SMEs
}

\author{
Rajshekar G. Javalgi \\ Cleveland State University, r.javalgi@csuohio.edu \\ Patricia R. Todd \\ Western Kentucky University, patricia.todd@wku.edu \\ Wesley J. Johnston \\ University of the West Indies
}

EPdlev柏ifołnd additional works at: https://engagedscholarship.csuohio.edu/bus_facpub

'kaland Sf State University e.granot@csulghio edu Operations Commons, and the International Business

\section{Commons}

How does access to this work benefit you? Let us know!

\section{Publisher's Statement}

NOTICE: this is the author's version of a work that was accepted for publication in the Journal of Business Research. Changes resulting from the publishing process, such as peer review, editing, corrections, structural formatting, and other quality control mechanisms may not be reflected in this document. Changes may have been made to this work since it was submitted for publication. A definitive version was subsequently published in Journal of Business Research, 65, 6, 06-01-2013, 10.1016/j.jbusres.2010.12.010

\section{Original Published Citation}

Javalgi, R.G., Todd, P.R., Johnston, W.J., \& Granot, E. (2012). Entrepreneurship, muddling through, and Indian internet-enabled SMEs. Journal of Business Research, 65(6), 740-744. doi:10.1016/ j.jbusres.2010.12.010

This Article is brought to you for free and open access by the Monte Ahuja College of Business at EngagedScholarship@CSU. It has been accepted for inclusion in Business Faculty Publications by an authorized administrator of EngagedScholarship@CSU. For more information, please contact library.es@csuohio.edu. 


\title{
Entrepreneurship, muddling through, and Indian Internet-enabled SMEs
}

\author{
Rajshekhar (Raj) G. Javalgi ${ }^{\text {a,*}}$, Patricia R. Todd ${ }^{\text {b }}$, Wesley J. Johnston ${ }^{\text {c }}$, Elad Granot ${ }^{\text {a }}$ \\ a Cleveland State University, United States \\ b Western Kentucky University, United States \\ ${ }^{c}$ The University of the West Indies, Mona, Jamaica
}

\section{Introduction}

The evolution of technology and the global diffusion of the internet enable firms to transcend their domestic boundaries and expand into international markets (Todd and Javalgi, 2007). The results include the growth of new enterprises, the transformation of small and medium-sized enterprises (SMEs) into multinational enterprises, and the evolution of new business models. New opportunities have been created for Internet-enabled firms that have been able to embrace uncertainty and risk. Advancements in the Internet and related technologies can enable smaller firms to become more entrepreneurial in their delivery of products and services.

Small and medium-sized enterprises in emerging markets such as India create a competitive advantage, especially by providing services driven by the information technology (IT) industry (Todd and Javalgi, 2007). Indian entrepreneurs are engaging in new innovations, using new business models to achieve scale and scope as they begin to compete in a global marketplace. This entrepreneurial drive enables them to identify and seize opportunities through their ability to focus on innovation, while remaining flexible enough to efficiently utilize limited resources so that operating in a changing market is to their advantage.

\footnotetext{
* Corresponding author. Marketing and International Business, Department of Marketing, James J. Nance College of Business, Cleveland, OH 44114, United States. Tel.: +1216 6874789 .

E-mail address: r.javalgi@csuohio.edu (R.(R.)G. Javalgi).
}

An understanding how these Indian entrepreneurs are successfully growing and rapidly expanding their businesses is critical, not only from research perspective, but also from a practitioner view. However, research focusing on the rational used by entrepreneurs in their decision making process is lacking. The study here contributes to the understanding of entrepreneurship in SMEs in emerging markets such as India. This contribution results through the examination of companies adopting the incremental decision making methods that Lindblom (1959) proposes.

The study here focuses on an emerging market such as India because of the following reasons. The importance of the SME sector and its impact on the overall economic growth of India through job creation as well as increasing prosperity has been well documented. India's foreign trade has been steadily growing. In 2005, the small business sector in India consisted of 3.5 million businesses, accounting for $42 \%$ of manufacturing turnover, $45 \%$ of employment, and $35 \%$ of exports (Rastogi, 2005). The following section presents relevant literature relating to entrepreneurial opportunities and Lindblom's incremental decision-making models.

\section{Literature review}

\subsection{Entrepreneurial opportunity and entrepreneurship}

The ability to see things differently and to develop a compelling vision for the future is one of the important attributes of the successful entrepreneur (Ardichvili, Cardozo and Sourav, 2003). As noted by researchers (Shane and Venkataraman, 2000; Styles and Seymour, 
2006), opportunity identification is the hallmark of entrepreneurship research. Schumpeter (1961) sees technological inventions as important sources for innovators, but also lists political, social, and macroeconomic changes as potential sources of opportunities.

Creative and innovative decisions characterize entrepreneurial opportunities. Entrepreneurs make these decisions within an environment plagued by uncertainty regarding the consequences of realizing the opportunity (Eckhardt and Shane, 2003). Entrepreneurial opportunity refers to: “... situations in which new goods, services, raw materials, markets, and organizing methods can be introduced through the formation of new means, ends, and means-ends relationships. These situations do not need to change the terms of economic exchange to be entrepreneurial opportunities, but only need to have the potential to alter in terms of economic exchange" (Eckhardt and Shane, 2003, p. 336).

How entrepreneurial opportunities are formed and exploited is referred to with such names as the "discovery theory of entrepreneurship" (Shane, 2003). Discovery Theory assumes that opportunities arise from competitive imperfections in markets or industries (for example, information technology) due to changes in technology, changing consumer preferences, or some other attributes of the context within which an industry or market exists (Kirzner, 1973). In this theoretical perspective, the role of the entrepreneur is to become aware of the opportunities in the market or industry and seize those that are of greatest economic benefit (Shane, 2003; Kirzner, 1973).

Another view contributing to understanding the formation and exploitation of opportunities has been discussed; this view is referred to as Creation Theory. In this approach, the actions of entrepreneurs themselves create entrepreneurial opportunities (Sarasvathy, 2001; Baker and Nelson, 2005). In this view, where the future is uncertain and ambiguous, rational decision making tools, such as risk-based decision making models, are of limited value (Wiltbank, Dew, Read, and Sarasvathy, 2006). Under these conditions, entrepreneurs appear to make decisions using approaches such as biases and heuristics (Busenitz and Barney; 1997, Wiltbank et al., 2006). Busenitz and Barney (1997) discuss two cognitive biases that are useful for entrepreneurs making decisions under conditions where the environment is uncertain. The two cognitive biases are the overconfidence bias and the representativeness bias. Creation Theory suggests that entrepreneurs seem to employ these biases in their decision to engage in specific entrepreneurial activities (Hayward, Shepherd, and Griffin 2006).

A review of the management, entrepreneurship, and political science literature also suggests that different sets of tools for decisionmaking can be applied in conjunction with, or as a substitute for, cognitive biases. This alternative method to decision making in these and other disciplines has been labeled differently. For instance, in entrepreneurship literature, there is a decision-making approach known as effectuation (Sarasvathy, 2001), in strategic management, it is labeled as emergent strategy formulation, and in political science, it is referred to as muddling-through (Lindblom, 1959).

Researchers have developed several different definitions of entrepreneurship (Lumpkin and Dess 1996; McDougall and Oviatt 2000, Oviatt and McDougall, 2005; Shane 2003). Shane (2003), for example, defines entrepreneurship as "an activity that involves the discovery, evaluation, and exploitation of opportunities to introduce new goods and services, ways of organizing, markets, processes, and raw materials through organizing efforts that previously had not existed." In this view, opportunities arise from factors such as technological, social and demographic changes in a country. Shane (2003) further underscores that discovery and exploitation of the opportunities require a creative act by the entrepreneurs. Given the business demands regarding globalization, coupled with the technological advancements and the rising significance of emerging markets, for the sake of both theoretical development and practical implications, the discussions regarding the entrepreneurial opportunities and entrepreneurship continue. These ongoing discussions provide new insights as the field evolves.

\subsection{Incremental decision making}

Decision-making is undertaken in everyday situations, in all walks of life, as a means of solving particular problems that come with different assumptions creating uncertainty and increased complexity. Different models of decision making are useful for business managers and strategists in conceptualizing decisions. Some of the well-known models include the root method and the incremental model. This article focuses on the incremental decision making model developed by Lindblom (1959, 1979).

The root method involves a thorough, in-depth evaluation of all options available to meet defined objectives. Analysis is comprehensive in the sense that every important relevant factor is taken into consideration. Decision-making is typically formalized as a meansends relationship (Lindblom, 1979). Using the root method, all factors impacting the business are considered simultaneously as a comprehensive decision making model.

Lindblom (1959) declares that the root method was impossible to follow, as the amount of information gathering that was necessary to scientifically evaluate the decision situation could not practically be performed. Therefore, the branch approach, or muddling through, was the approach that more closely resembled reality. Rather than compelling decision makers to attempt to consider and react to all possible options comprehensively, in the successive-limited comparisons or the branch method, decision makers proceed step-by-step in small increments. This significantly reduces the number of decision factors and alternatives available.

In considering the root method, the decision maker relies heavily on the theoretical underpinnings. In the incremental approach, the reliance on theory is greatly reduced. Hence, the test of a "good policy" is that analysts find themselves agreeing on the policy, without agreeing that it is the most desirable means to an agreed objective (Lindblom, 1959; 1979). Although, on the surface, Lindblom's model seems simple, it involves a complex set of decision choices that occur as the decision maker is faced with a new alternative, compares it to the status quo, and then, with limited information, either accepts or rejects the new choice, repeating the cycle over time (Bender, 1995).

The following section focuses on three examples of entrepreneurial companies in the emerging markets of India that survived the dotcom bust to successfully build and grow in a highly competitive and uncertain environment. Qualitative research methodology utilizing a case study format, taking advantage of secondary sources, was used. This approach is useful for expanding and generalizing theories by combining the existing theoretical knowledge with practitioner behavior to gain an understanding of complex decision making processes (Eisenhardt and Graebner, 2007; Gummesson, 2006; Yin 1994). Data are collectable from a variety of sources including corporate reports, firm websites, and business news. The case method enables research to be conducted in emerging markets where the sample base is too small to allow statistical generalization (Chetty, 1996).

\section{Company examples from India}

The three cases chosen for this study include Info Edge, a broad based, Internet firm leading the four areas in which it focuses; Makemytrip, the leading Internet travel service provider in India, and Indiamart, the leading supplier of an inventory of products in India. All are purely dot-com companies, all have created a sustainable competitive advantage and survived the dot-com bust through the innovative management style of their entrepreneurial leaders. All are examples of companies whose growth can be examined through the 
lens of the muddling through approach as outlined by Lindblom (1959, 1979).

\subsection{Case1: Info Edge}

Info Edge is a leading online service provider business consisting of the following five divisions: online recruitment classified division, online matrimonial classified division, online real estate classified division, executive search division, and online educational classified division Infoedge.com (2009a,b). They have also launched corresponding sites that target consumers in the Middle East (Infoedge.com, 2009a,b). The company's commitment to an entrepreneurial focus is illustrated in their mission statement. "We will continuously delight our customers in current and new businesses by delivering superior value through enhanced offerings on the Internet and other platforms. We will do this by preserving our entrepreneurial spirit and leveraging our financial strength and expertise in building brands, communities, product and technology, and sales and service" (Infoedge.com, 2009a,b).

The CEO of Info Edge refers to "new age" entrepreneurs and the importance of being able to be resilient during economic difficulties, developing strategy to conserve in lean times without sacrificing long term strategic opportunities (Infoedge.com, 2009a,b). The foundation of Info Edge is the site naukri.com, established in 1997 as a job portal, which has now grown to be the leading job search site in India (Infoedge.com, 2009a,b). The business then diversified over time as illustrated in Table 1.

The online media company concentrates on operating in a virtual environment, utilizing online technology to reach its target market, which consists of the young, upwardly mobile, population of India (Infoedge.com, 2009a,b). India has a rapidly growing middle class and, as Internet technology continues to evolve, consumers will be taking advantage of the utilization of their purchasing capabilities (Lacy, 2009). The company has grown in a step-by-step manner through diversification using online technology as its primary platform.

This incremental growth is consistent with the decision making approach that Lindblom $(1959,1979)$ outlines. The CEO of Info Edge credits much of the success of the company to its resilience in difficult

\section{Table 1}

Info Edge: summary of business expansions.

Source: Retrieved from http://www.infoedge.in/ on September 15, 2009.

\begin{tabular}{|c|c|}
\hline Infoedge (1997) & $\begin{array}{l}\text { India's leading internet classifieds company with } 67 \text { offices in } \\
\text { India, Dubai, Bahrain and Riyadh. }\end{array}$ \\
\hline $\begin{array}{l}\text { Naukri.com } \\
\quad(1997)\end{array}$ & $\begin{array}{l}\text { Provides recruitment classifieds and services to job seekers, } \\
\text { employers and recruiters. }\end{array}$ \\
\hline $\begin{array}{l}\text { Quadrangle } \\
\text { (2000) }\end{array}$ & $\begin{array}{l}\text { India's leading executive placement firm providing expert and } \\
\text { innovative services through its network of offices in major cities } \\
\text { across India. }\end{array}$ \\
\hline $\begin{array}{l}\text { Jeevansathi.com } \\
\text { (2004) }\end{array}$ & $\begin{array}{l}\text { Matrimonial website, focusing on the northern and western } \\
\text { Indian markets, ranking third in India. }\end{array}$ \\
\hline $\begin{array}{l}\text { 99acres.com } \\
\text { (2005) }\end{array}$ & $\begin{array}{l}\text { One of India's first platforms to cater to the online real estate } \\
\text { market, a service bringing together brokers, buyers and sellers } \\
\text { over an online medium. }\end{array}$ \\
\hline $\begin{array}{l}\text { Allcheckdeals. } \\
\text { com (2005) }\end{array}$ & $\begin{array}{l}\text { India's first and only online brokerage of real estate, providing } \\
\text { full real estate services from the initial property search to } \\
\text { financing and payment services. }\end{array}$ \\
\hline $\begin{array}{l}\text { Naukri.com, Gulf } \\
\text { (2006) }\end{array}$ & $\begin{array}{l}\text { Provides recruitment classifieds and services to job seekers, } \\
\text { employers and recruiters in the middle eastern market with } \\
\text { offices in Dubai, Bahrain and Riyadh. }\end{array}$ \\
\hline $\begin{array}{l}\text { Asknaukri.com } \\
\quad(2007)\end{array}$ & $\begin{array}{l}\text { Brings a team of experts in the area of work and life } \\
\text { development, answering all employment and job-hunting } \\
\text { related questions. }\end{array}$ \\
\hline Brijj.com (2007) & Professional networking site with 1.6 million registrants. \\
\hline $\begin{array}{l}\text { Shiksha.com } \\
\text { (2008) }\end{array}$ & Provides free higher education counseling services. \\
\hline $\begin{array}{l}\text { FirstNaukri.com } \\
\text { (2009) }\end{array}$ & $\begin{array}{l}\text { One of the largest job search networks for college students and } \\
\text { recent graduates, maintaining the largest database of students } \\
\text { in India. }\end{array}$ \\
\hline
\end{tabular}

times and an optimistic attitude toward the long term, future growth of their diversified businesses in India. The directors' report at the close of the fiscal year, March, 2010 states that the company is anticipating a steady growth in Internet based businesses, attributed to the increase in the number of upwardly mobile consumers in India (Indiaearnings.moneycontrol.com, 2010). The company remains in a position of strength due to the development of strong business fundamentals. This, along with cash included in their liquid assets, gives them a competitive advantage.

\subsection{Case 2: Makemytrip.com}

MakeMyTrip (India) Pvt., Ltd. operates India's premier website, acting as an online travel agency. It provides booking services for flights, hotels, and buses; and holiday packages and travel guides. The company was founded in 2000 and is headquartered in Gurgaon, India. Even though the acceptance of Internet transactions was slower in India, travel bookings have grown $88 \%$ during a recessionary economy (Lacy, 2009). Since its launch, MakeMyTrip has grown rapidly to become the largest issuer of airline tickets, as well as, the leading seller of hotel reservations and holidays in India (makemytrip.com, 2009). Deep Kalra, founder and CEO, gives much of the credit for his success to the growth of Internet technology. According to Kalra, travel is one of the few services that deliver its product by email, subsequently significantly reducing the operation costs, especially for companies doing business from emerging markets where distance becomes a large contributor to increased cost (Lacy, 2009).

Their initial market was negatively impacted, between 2001 and 2002, by several uncontrollable factors: 1 . the terrorist bombings in September 2001, 2. the dot-com bust, 3. the attack on Indian Parliament in 2001, and 4. the SARS epidemic. Faced with these challenges, the company took incremental steps to insure its longevity. First, they halted all marketing in India and changed their target to the non-resident Indian market. This was a deliberate decision and is consistent with the philosophy of Deep Kalra. As an entrepreneur, he believes that in order to be successful in a chaotic environment, the audience must be identified, spending must be consistent with the target market, and a buffer of cash or a line of credit must be accessible. There is no time in the turbulent environment to wait for extensive study, sometimes you have to apply common sense (Podtech.net, 2006). His commitment to his business and employees, assuming risk in a time of uncertainty is used an example for new entrepreneurs. MakeMyTrip was a business model that was ahead of its time in India, but through persistence and his ability to assume risk, Kalra has taken the steps through turbulent times to grow the business to over $\$ 500$ million in gross bookings (Lacy, 2009). On August, 2010 Makemytrip.com was listed in NASDAQ. The initial offering of five million shares raised $\$ 70$ million and the share price rose $89 \%$ with a subsequent market cap of over a billion dollars (Ramnath et al., 2010). This company business model exemplifies the concept as espoused by Lindblom $(1959,1979)$.

\subsection{Case 3: Indiamart.com}

Indiamart was founded in 1996. It is India's largest business-tobusiness marketplace connecting global buyers with suppliers through business directories, online product catalogs, buy-sell offers, industry specific marketplaces, and participation in trade shows. With over 1000 employees, IndiaMart.com offers a broad range of valueadded products and services to over 50,000 members and 5 million global buyers (www.businesswireindia.com) (Businesswireindia.com, 2010). The web-based company assists buyers and sellers trade with each other on a reliable, common platform. There are over 15,000 catalogs and 700,000 products. Indiamart.com actively participates in more than 75 international and 150 domestic trade 
shows, features over 300,000 suppliers, and represents over 20,000 product categories as listed on the website (Indiamart.com, 2009).

For the last fourteen years, IndiaMART.com has been playing an aggressive role in promoting India's SMEs business through its online platform, assisting them in selling their products and services in the international marketplace and expanding their business opportunity globally. In order to survive turbulent times, the company focused on cost cutting and resource optimization. The focus became leveraging core competencies and divesting non-core products. Several welltargeted products were launched in an effort to explore new markets. Optimization of sales and support cycles resulted in improving the firm's ability to explore new business opportunities (Indiamart.com, 2009). According to the Founder and CEO, the future growth of Indiamart will be a result of growth of service offerings, expansion into new markets outside of India and taking advantage of new strategic opportunities (pr.com/press-release/126930, 2010). Once again, incremental changes were made to its operating policies because of environmental pressures. A step-by-step, incremental process was followed as the firm considered focusing on new markets and added new products to their website.

\section{Discussion and conclusions}

The current global business environment is best characterized as turbulent and ever changing. As firms struggle to grow their business, strategy must be developed to support their survival. Opportunities to create new economic value arise because of competitive imperfections in industry or product markets (Shane and Venkataraman, 2000). These competitive imperfections may reflect changes in information technology, demand, or other factors that individuals or groups in an economy attempt to exploit (Kirzner, 1973; Shane, 2003; Alvarez and Barney, 2007), or they may be created by the purposeful actions of these individuals or groups (Alvarez and Barney, 2005).

Entrepreneurship in India has been encouraged, initially through government policies providing protection to small businesses (Sheth, 2004). In 1997, federal initiatives moved from a focus on protectionism to one of promoting stability and growth (Manimala, Gopal, Prakhya, and Shields, 2001). Economic and social integration make it necessary for managers in India to focus on the international business environment (Sheth, 2004). Indian executives are optimistic about the future and see the opening of the global markets as an opportunity for expansion (Bever, Stephenson, and Tanner, 2005). Indian entrepreneurs are leveraging technological capabilities for their competitive advantage (Todd and Javalgi, 2007). Small and medium size business owners and entrepreneurs in emerging markets such as India, faced with an increasingly turbulent business environment, are confronted with so many challenges that, instead of rational models of problem solving, they are forced to develop alternative strategies to succeed.

In the age of information, one cannot take the time to study and develop a business plan taking into account all of the possible impacting factors present in the complex business arena. This is a prime area to apply Lindblom's branch method of decision-making. More specifically, due to advances in information technology and governmental reform, India represents an environment in which small and medium-sized businesses can effectively utilize Lindblom's approach. Looking at these companies through the muddling through perspective, the branch method may apply as an explanation for the success in the turbulent environment in which they operate. Their growth strategy was built in an incremental, step-by-step manner, in which the next step built on the previous one.

Infoedge began as a job portal and then branched into many other businesses, using information technology to enable its growth. In contrast, MakeMyTrip (India) Pvt., Ltd, again, relying on information technology as a distribution method, did not have time to take into consideration all possible strategic alternatives when their business was negatively impacted by uncontrollable environmental factors. Indiamart also underwent growth through the incremental addition of suppliers to their base of business partners. In each example, the firms were operating in turbulent times and all were following the approach of making decisions without using a comprehensive, analytical approach.

In conclusion, the ubiquity of the Internet has increased the pace of globalization and stimulated the growth of e-commerce in such emerging markets as India. The examples presented in this paper represent companies that have survived despite the turbulence present in their business environments. All of them rely on the Internet for delivery of their services. They are also successful in growing the risky, ever-changing emerging market of India. Each example represents a slightly different business strategy, but each can be examined from the perspective of the process of muddling through.

Academic enquiry to date has merely skimmed the surface as to how small Internet-enabled firms in emerging markets grow both domestically and internationally. Much work needs to be done on how business owners, international managers, and entrepreneurs use rational decision-making models such as Lindblom's concept of decision-making.

\section{Acknowledgments}

The authors thank anonymous reviewers for their constructive comments and suggestion on the manuscript. Also, we would like to thank Minna Rollins, University of West Georgia, and. Hannu Makkonen, Univesit of Turku.

\section{References}

Alvarez SA, Barney JB. How entrepreneurs organize firms under conditions of uncertainty. J Manage 2005;31:776-93.

Alvarez SA, Barney JB. The entrepreneurial theory of the firm. J Manage Stud 2007;44(7):1057-63.

Ardichvili A, Cardozo R, Sourav R. A theory of entrepreneurial opportunity identification and development. J Bus Venturing 2003;18:105-23.

Baker T, Nelson R. Creating something from nothing: resource construction through entrepreneurial bricolage. Admin Sci Quart 2005:50:329-66.

Bender J. A model of muddling through. Am Pol Sci Rev 1995;89(4):819-40.

Bever EJ, Stephenson E, Tanner DW. How India's executives see the world. McKinsey Q 2005:34-41.

Busenitz LW, Barney JW. Differences between entrepreneurs and managers in large organizations: biases and heuristics in strategic decision-making. J Bus Venturing 1997;12(6):9-30.

Businesswireindia.com, IndiaMART.com partners with NDTV to launch SME initiative, Press Release www.Businesswireindia.com/PressRelease.asp?b2mid=20703, accessed 3/23/2010.

Chetty S. The case study method for research in small and medium sized firms. Int Small Bus J 1996;15(1):73-85.

Eckhardt JT, Shane SA. Opportunities and entrepreneurship. J Manage 2003;29(3): 333-49.

Eisenhardt KM, Graebner ME. Theory building from cases; opportunities and challenges. Acad Manage J 2007;50(1):26-32.

Gummesson E. Qualitative research in management: addressing complexity, context, and persona. Manage 2006;44(2):167-79 Dec.

Hayward M, Shepherd DA, Griffin D. A hubris history of entrepreneurship. Manage Sci 2006;52(2):160-72.

Indiamart.com, Corporate Fact Sheet, http://www.intermesh.net/fact-sheet.html, accessed September 24, 2009.

Indiaearnings.moneycontrol.com/sub_india/reports.php?sc_did=IEI01\&type $=$ directorsreport, accessed November 8, 2010

Infoedge.com, Quick Facts/Milestones, http://www.infoedge.in/corporate-quick-factsmilestones.asp, accessed September 24, 2009.

Infoedge.com, Vision, Mission \& Values, www.infoedge.in/corporate-vision-missionvalues.asp, accessed September 24, 2009.

Kirzner I. Competition and entrepreneurship. Chicago and London: University of Chicago Press; 1973.

Lacy, S. Is eCommerce in India finally happening? Media post on Makemytrip.com: http://techcrunch.com/2009/11/13/makemytrip-com-is-ecommerce-in-indiafinally-happen, retrieved 3/25/10

Lumpkin GT, Dess GC. Clarifying the entrepreneurial orientation construct and linking it to performance. Acad Manage Rev 1996;21(1):135-72.

Lindblom CE. The science of muddling through. Pub Admin Rev 1959;19:79-88. 
Lindblom CE. Still muddling through. Pub Admin Rev 1979;39:517-26.

makemytrip.com, Company Profile, http://www.makemytrip.com/about-us / company_profile.php, accessed September 24, 2009.

Manimala MJ, Gopal MV, Prakhya S, Shields J. GEM India report. Bangalore, India: Indian Institute of Management; 2001.

McDougall PP, Oviatt BM. International entrepreneurship: the intersection of two research paths. Acad Manage J 2000;43(5):902-6.

Oviatt BM, McDougall PP. Defining international entrepreneurship and modeling the speed of internationalization. Entrep Theo Prac 2005:537-53.

Podtech.net, online podcast interview, http://media.podtech.net/media/2006/12/PID_001545/Podtech_t_1587-deep-kalra-of-makemytri.html, 2006.

pr.com/press-release/126930, IndiaMART.com funding reinforces success of Indian SMEs, accessed 11/08/2010.

Ramnath, NS, D'Souza, N. Is the dotcom craze back? http://business.in.com/article/realissue/is-the-dotcom-craze-back/17242/1. accessed 11/08/2010.

Rastogi R. Initiatives for e-commerce capacity-building of SMEs in India. Country Presentations 2005:147-57.
Sarasvathy SD. Causation and effectuation: toward a theoretical shift from economic inevitability to entrepreneurial contingency. Acad Manage Rev 2001;26(2): 243-88.

Shane S. A general theory of entrepreneurship: the individual-opportunity nexus. Northampton, MA: Edward Elgar 2003; Cheltenham; 2003.

Shane S, Venkataraman S. Promise of entrepreneurship as field of research. Acad Manage Rev 2000;25(1):217-26.

Sheth J. Making India globally competitive. Vikalpa 2004;29(4):1-9.

Styles C, Seymour R. Opportunities for marketing researchers in international entrepreneurship. Int Market Rev 2006;23(2):126-45.

Schumpeter J. The theory of economic development. Cambridge, MA: Harvard University Press; 1961. New York: Oxford University Press.

Todd P, Javalgi R. Internationalization of SMEs in India: fostering entrepreneurship by leveraging information technology. Int J Emerg Mark 2007;2(2):166-80.

Wiltbank R, Dew N, Read S, Sarasvathy SD. What to do next? The case for nonpredictive strategy. Strat Manage J 2006;27:981-98.

Yin RK. Case study research design and methods. London: Sage; 1994. 